\title{
Evaluation of groundwater potential using geospatial techniques
}

\author{
Abdul-Aziz Hussein $^{2} \cdot$ Vanum Govindu $^{1} \cdot$ Amare Gebre Medhin Nigusse $^{1}$
}

Received: 25 December 2015/Accepted: 23 May 2016/Published online: 17 June 2016

(c) The Author(s) 2016. This article is published with open access at Springerlink.com

\begin{abstract}
The issue of unsustainable groundwater utilization is becoming increasingly an evident problem and the key concern for many developing countries. One of the problems is the absence of updated spatial information on the quantity and distribution of groundwater resource. Like the other developing countries, groundwater evaluation in Ethiopia has been usually conducted using field survey which is not feasible in terms of time and resource. This study was conducted in Northern Ethiopia, Wollo Zone, in Gerardo River Catchment district to spatially delineate the groundwater potential areas using geospatial and MCDA tools. To do so, eight major biophysical and environmental factors like geomorphology, lithology, slope, rainfall, land use land cover (LULC), soil, lineament density and drainage density were considered. The sources of these data were satellite image, digital elevation model (DEM), existing thematic maps and metrological station data. Landsat image was used in ERDAS Imagine to drive the LULC of the area, while the geomorphology, soil, and lithology of the area were identified and classified through field survey and digitized from existing maps using the
\end{abstract}

Vanum Govindu

govindu_gis@yahoo.com

Abdul-Aziz Hussein

saadsiham6@gmail.com

Amare Gebre Medhin Nigusse

amarenigusse@gmail.com

1 Department of Geo-Information and Earth Observation Sciences for Natural Resource Management, Institute of GeoInformation and Earth Observation Sciences, Mekelle University, Mekelle, Ethiopia

2 Institute of Geo-Information and Earth Observation Sciences, Mekelle University, Mekelle, Ethiopia
ArcGIS software. The slope, lineament and drainage density of the area were derived from DEM using spatial analysis tools. The rainfall surface map was generated using the thissen polygon interpolation. Finally, after all these thematic maps were organized, weighted value determination for each factor and its field value was computed using IDRSI software. At last, all the factors were integrated together and computed the model using the weighted overlay so that potential groundwater areas were mapped. The findings depicted that the most potential groundwater areas are found in the central and eastern parts of the study area, while the northern and western parts of the Gerado River Catchment have poor potential of groundwater availability. This is mainly due to the cumulative effect of steep topographic and high drainage density. At last, once the potential groundwater areas were identified, cross validation of the resultant model was carefully carried out using existing data of dung wells and bore holes. The point data of dung wells and bore holes were overlaid on groundwater potential suitability map and coincide with the expected values. Generally, from this study, it can be concluded that RS and GIS with the help of MCDA are important tools in monitoring and evaluation of groundwater resource potential areas.

Keywords Groundwater - Gerardo River - Geospatial · MCDA - Spatial information

\section{Introduction}

Groundwater is one of the most valuable natural resources supporting human health and economic development. Because of its continuous availability and excellent natural quality, it becomes an important source of water supply in 
both urban and rural areas of any country (Todd and Mays 2005). It also helps in poverty alleviation and reduction, i.e., can be delivered directly to the poor community far more cheaply and quickly than the canal water (IWMI 2001).

Of the total of freshwater estimated to be present on the earth, around $22 \%$ of it exists in the form of groundwater, and it constitutes around $97 \%$ of all liquid freshwater available which is used for human consumption (Foster 1998). But, the mismanagement of groundwater resource to supply ever increasing demand finally leads to water shortages and pollution (De Villiers 2000; Tsakiris 2004).

Therefore, unsustainable groundwater use is becoming increasingly apparent and the key concern, particularly in developing countries (Todd and Mays 2005) like in Ethiopia. People have to use water efficiently in an ecologically sound manner for present and future generations, since it is a very limited resource. To do so, adopting advanced geospatial tools are very vital to continuously assess and monitor the groundwater resource status periodically.

Recently, digital satellite data can provide quick and useful baseline information about the factors controlling the occurrence and movement of groundwater. Updated information on geology, land cover, lineaments and others factors controlling groundwater can easily be accessed freely (Bobba et al. 1992; Meijerink et al. 2000). However, all the controlling factors had rarely been studied together because of the non-availability of data and integrating tools.

Now days, geospatial tools have emerged as effective tools for executing spatial data and decision making in several areas including engineering and environmental fields (Stafford et al. 2008; Goodchild 1993). RS and GIS are among those geospatial tools, i.e., are important for analysis of voluminous hydrogeological data and for the simulation modeling of complex features (Watkins et al. 1997; Loague and Corwin 1998; Gogu et al. 2001; Gossel et al. 2004).

In Ethiopia, most of hydrogeological investigations and groundwater potential evaluation have been done traditionally, using in situ measurement which is not feasible. In the study area, some studies had been conducted earlier for different purposes. The geohydrogeological investigations and inventory of land slide susceptibility in the area were conducted earlier by Ethiopian Geological Survey (Bayessa et al. 2002; AWSD 2002), respectively.

Dereje (2012) also carried out groundwater potential assessment investigation in the study area. Of these conducted studies in the area, almost all of these studies hardly evaluated the prospective groundwater of the area with the advance application geospatial and MCDA tools. Hence, the aim of the study was to apply geospatial technologies and multicriteria analysis decision analysis in groundwater potential mapping in Gerado River, Northern Ethiopia.
Such up to date information will be a great importance for the researchers, practicing hydrogeologists and decision makers to pass right decisions timely.

\section{Study area description}

The study area is located in the Ethiopian Highland Plateau adjoining the Western Escarpment of the Rift Valley and found in the Abay River Basin, look Fig. 1. The general topography of the catchment is characterized by undulating hills, plane and valley. Its elevation ranges from 1965 to $3552 \mathrm{~m}$ masl and bounded within 552,428-572,576E and 1210,451-1243,825N (UTM/ADINDAN), respectively. The annual average temperature of the study area is $17^{\circ} \mathrm{C}$.

\section{Methodology}

\section{Pre-field and fieldwork activities}

The methodology designed for this research work consisted of three major phases: pre-fieldwork, fieldwork and post fieldwork. In the pre-fieldwork, review of previous works on the matter study, reconnaissance survey area and other similar areas related to the topic had been carried out. Collections of appropriate data were done, giving particular attention to the quality of documents.

Geological and structural investigations were conducted in the fieldwork for identifying the major geological units and structural configurations in the study area. As a result, geological map of the area was produced. Hydrogeological field investigation was done by giving more attention on differentiating the sediments and rock units of groundwater significance such as the degree of fracturing of the rock units, space between fractures and opening space of fractures in the rocks.

\section{Post-fieldwork activities}

In the post-fieldwork, data processing analysis of primary and secondary data obtained from pre-field and fieldwork was the main activity. Some of the important activities were: delineating of the study area was initially done by extracting the catchment from topographic maps and DEM images using ArcGIS software. GPS readings from different locations of the study area were used for further ground checking.

After delineating the study area, base map preparation for each variable was undertaken using topographic maps with a scale of 1:50,000. To evaluate groundwater prospect of the area, identification and classification of the basic baseline maps of geomorphology, soil, lineament density, drainage density, land use land cover (LULC), slope, 


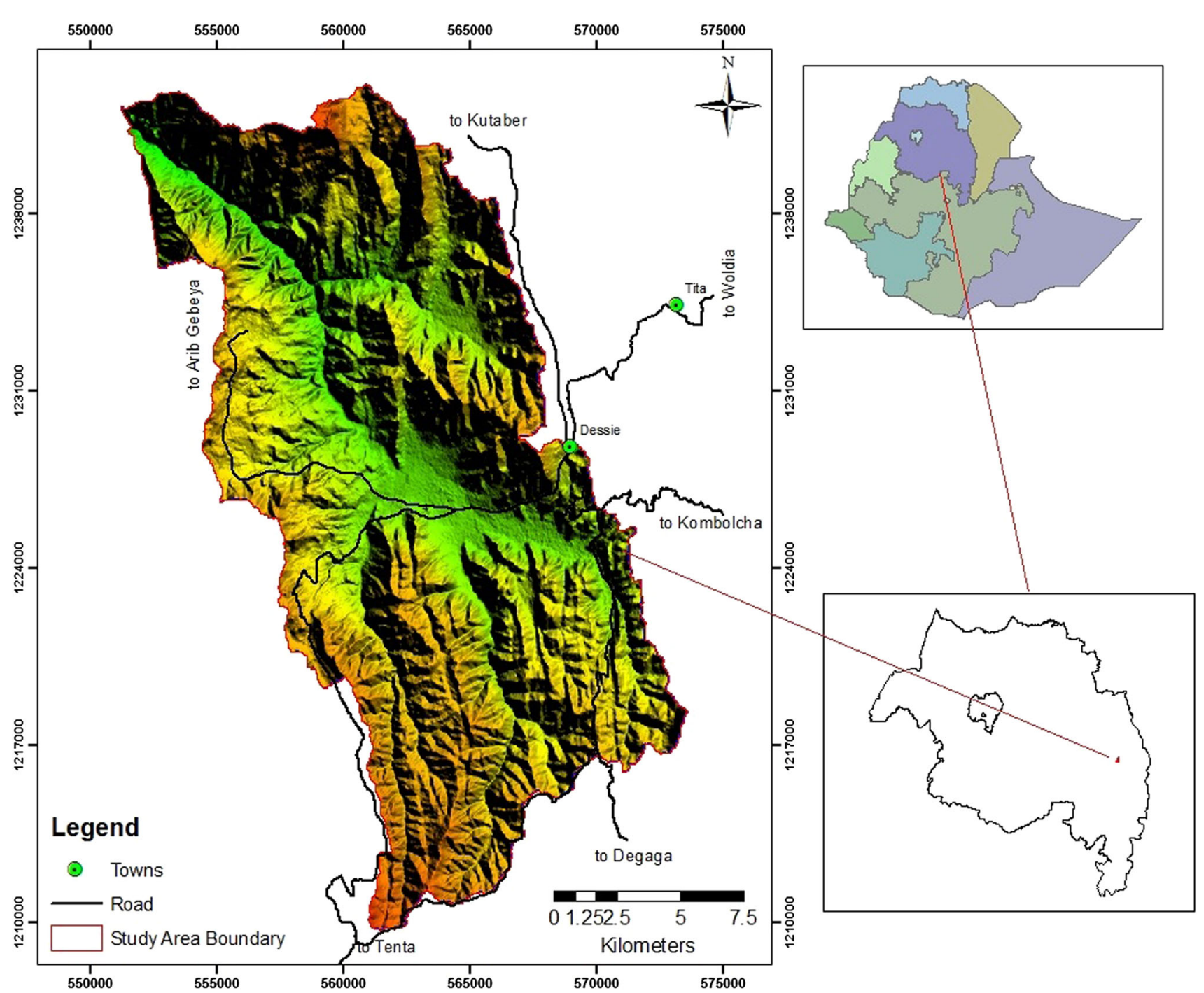

Fig. 1 Map of the study area

lithology and rainfall of the catchment were done. Then, different thematic baseline maps were prepared, in which they were used in simulation of the groundwater map suitability.

To begin with slope preparation of the area, a digital elevation model (DEM) with $30 \mathrm{~m}$ spatial resolution was used as in the ArcMap of ArcGIS, spatial analysis tool. Then, the study area's slope was classified into four classes with lowest and highest $c$ value of $5^{\circ}$ and $60^{\circ}$, respectively, as presented in Fig. 6. The flat and steep gradient of the area has significant impact on groundwater occurrence and movement.

The other determinant factor controlling groundwater occurrence is drainage density. It was calculated and mapped directly in the Arc map of ArcGIS, spatial analysis extension tool using DEM of $30 \mathrm{~m}$ spatial resolution. Accordingly, four drainage density categories were identified and mapped that are important in controlling groundwater occurrence and movement; see Fig. 7.

\section{Remote sensing activities}

The land use cover of the area was done using the multi spectral band of landsat satellite image of 2014, with $30 \mathrm{~m}$ spatial resolution. The image was freely downloaded from USGS and it was geometrically and radiometrically corrected in ERDAS Imagine 8.6. Then, supervised image classification was done for the image and four classes were identified and mapped; see Fig. 4. Those different LULCs have significant impact on groundwater occurrence and movement.

\section{Deterministic interpolation}

Rainfall measurement is a point observation and may not be used as a representative value for the area under consideration. Therefore, it is necessary to obtain effective uniform depth of rainfall of the catchment to get a more 
reliable and representative results. Areal depth of rainfall in the catchment was estimated using simple arithmetic mean, isohyetal and Thiessen polygon interpolation methods.

So, to create the surface map of the study area, metrological data from Dessie, Kombolucha, Albuko, Guguftu and Kutabor districts were used as source of point data. To calculate mean monthly rainfall of the study area, data from the metrological station were used using the arithmetic mean which is given below:

$\frac{p=p_{1}+p_{2}+p_{3} \ldots p_{n}}{N}$

where $P$ is the average depth of precipitation of the area, $P_{1}, P_{2}, P_{3}$ and $P_{n}$ are the rain fall records at stations $1,2,3$, and $N$ is the number of metrological stations. Although all the three types of interpolation methods were used for comparison purpose, isohyetal interpolation was found as the best technique interpolation. Because it takes into account the influence of physiographic parameters including elevation, slope and distance from the coast.

After all the determinant baseline maps were identified and prepared, weighted value estimation for each factor and its field value was computed as all the factors have no equal importance in controlling groundwater occurrence. And this was done using the multicriteria evaluation decision analysis and an IDRISI Software was used for this purpose.

At last, all maps were added together to ArcGIS Software, and weighted overlay method was used to finally to develop the groundwater potential model. However, it needs further validation to cross check whether the selected suitability classes are right or not. Accordingly, point data on water pump, bore hole and dung wells collected across the study area were used for accuracy assessment of the model.

\section{Results and discussion}

\section{Evaluating physical and environmental factors controlling groundwater occurrence}

\section{Geomorphology}

The main geomorphic units identified in the area are alluvial plain, mountainous area, plateau, and residual hills. Mountainous area and residual hills are the dominant types of geomorphological class in the area; see Fig. 2. As shown in Fig. 10, groundwater occurrence map, those suitable areas are found with geomorphic class of alluvia plain and plateau because of high infiltration rate.

Soumen (2014) also indicated that alluvial plain and plateau have more impact in occurrence groundwater, while the mountainous and residual hills areas have shown less impact in controlling groundwater.

A geomorphological terrain classification leading to the delineation of hydromorphological is useful, taking both morphological and lithological factors into consideration. DEM and SRTM data allow creating a detailed description of landforms useful for groundwater potential assessment (Solomon and Ghebreab 2008).

\section{Lithology}

Lithology is another factor controlling the quantity and quality of groundwater occurrence in a given area (Bhuvaneswaran et al. 2015). The area's lithology Fig. 3 is dominated by quaternary sediments and tertiary rocks and classified into alaji rhyolite, aiba basalt, tarmaber formation and alluvial deposits. The lithology influences on both the porosity and permeability of aquifer rocks (Ayazi et al. 2010; Chowdhury et al. 2003).

The most suitable groundwater potential areas are found in the lithology class of tarmaber formation and alluvial deposits as shown in Fig. 3 because of its good capacity of infiltration and water recharge.

However, each one of those lithological units has no equal significance in determining and controlling groundwater. To that end, the IDRIS Software was used to determine weighted value among lithological units. Accordingly, the result is put in order as follows: alluvial deposits $>$ tarmaber formation $>$ alaji rhyolite $>$ aiba basalt, respectively.

\section{Drainage density}

In the study area, four main drainage density categories have been identified and mapped as shown in Fig. 4. The field values of the drainage density vary from 0 up to 2.7. The very high drainage density areas are found in the northern part of the study area. In contrast, the very low drainage density areas are found in the eastern, western and central parts of the study area, while the rest areas within the moderate and low drainage densities are concentrated in the southern and central parts of the study area.

The coarse drainage texture indicates highly porous and permeable rock formations, whereas the fine drainage texture is more common in less pervious formations (Waikar and Nilawar 2014).

Structurally controlled drainage is normally seen in northern part of the study area. Drainage texture and patterns are controlled by different litho-units, structure and morphology. In the northern part of the area, the drainage pattern is sub-dendritic to sub-parallel. Groundwater potential is poor in areas with very high drainage density/course as it lost majority in the form of runoff. 


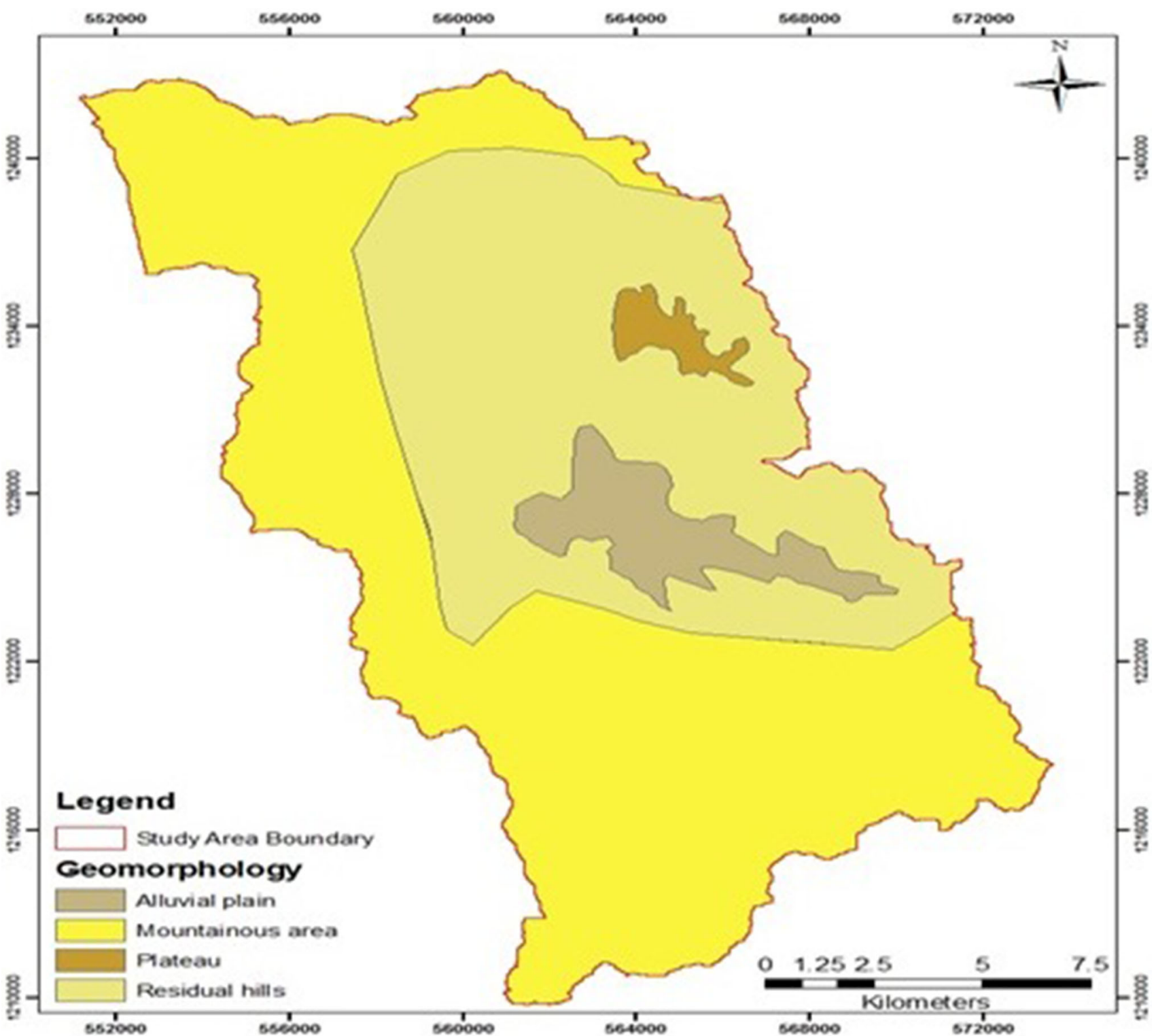

Fig. 2 Geomorphology of the study area

On the other hand, areas with low drainage density allow more infiltration to recharge the groundwater and, therefore, have more potential for ground water occurrence. Murasingh (2014) also noted that low drainage density region causes higher infiltration and it yields in better groundwater potential zones as correlated to a high drainage density region. In contrast, high drainage density values are favorable for runoff, and hence indicates low groundwater potential zone (Aggarwal et al. 2013).

However, each one of those lithological units has no equal importance in determining and controlling groundwater. So, similar approach was used to determine weighted value among lithological units. And the results are put in order as: alluvial deposits $>$ tarmaber formation $>$ alaji rhyolite $>$ aiba basalt, respectively.
Land use land cover

The land use/land cover of a certain area depends on geomorphology, agro-ecology, climate and human-induced activities. It is one of the factors affecting groundwater occurrence and availability. Supervised image classification was conducted to classify and to identify the type of LULC and four classes were identified. And those are namely cultivated land, grassland, forest and shrub. Land sat satellite image of 2014 with $30 \mathrm{~m}$ spatial resolution was used as source of data to drive the LULC map (Fig. 5).

Singh (2014) stated that LULC information is an important factor in groundwater storage and recharge. The type and nature of LULC on groundwater controlling in order of increment put as: plantation $>$ shrub land $>$ cultivation 
Fig. 3 Lithology of the study area

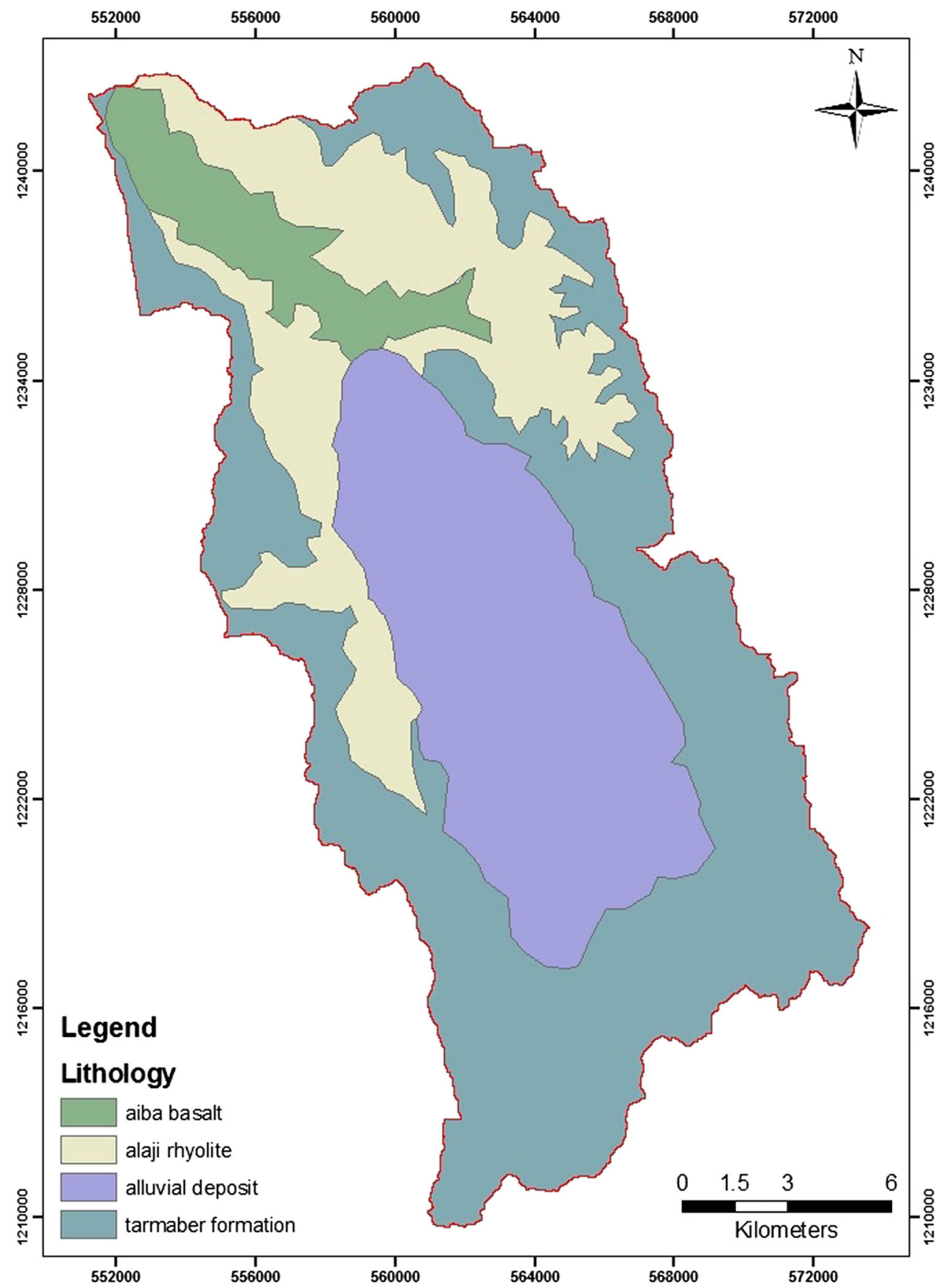

land $>$ grazing land. So, shrub land and planation areas are more suitable for groundwater occurence because of better infiltration. The degree of cultivation is highly intensified, due to the presence of good groundwater potential.

\section{Rainfall}

Rainfall measurement is a point observation and may not be used as a representative value for the area under consideration. Therefore, it is necessary to obtain effective uniform depth of rainfall of the study area to get a more reliable and representative results. Areal depth of rainfall in the catchment was estimated using simple arithmetic mean, isohyetal and Thiessen interpolation methods using the five metrological stations data.

Thiessen interpolation method provides for non-uniform distribution of rain gauge by determining a weighted factor for each gauge and it is generally more accurate than the arithmetic mean method, while isohyetal interpolation takes into account the influence of physiographic parameters including elevation, slope and distance from the coast 
Fig. 4 Drainage density of the study area

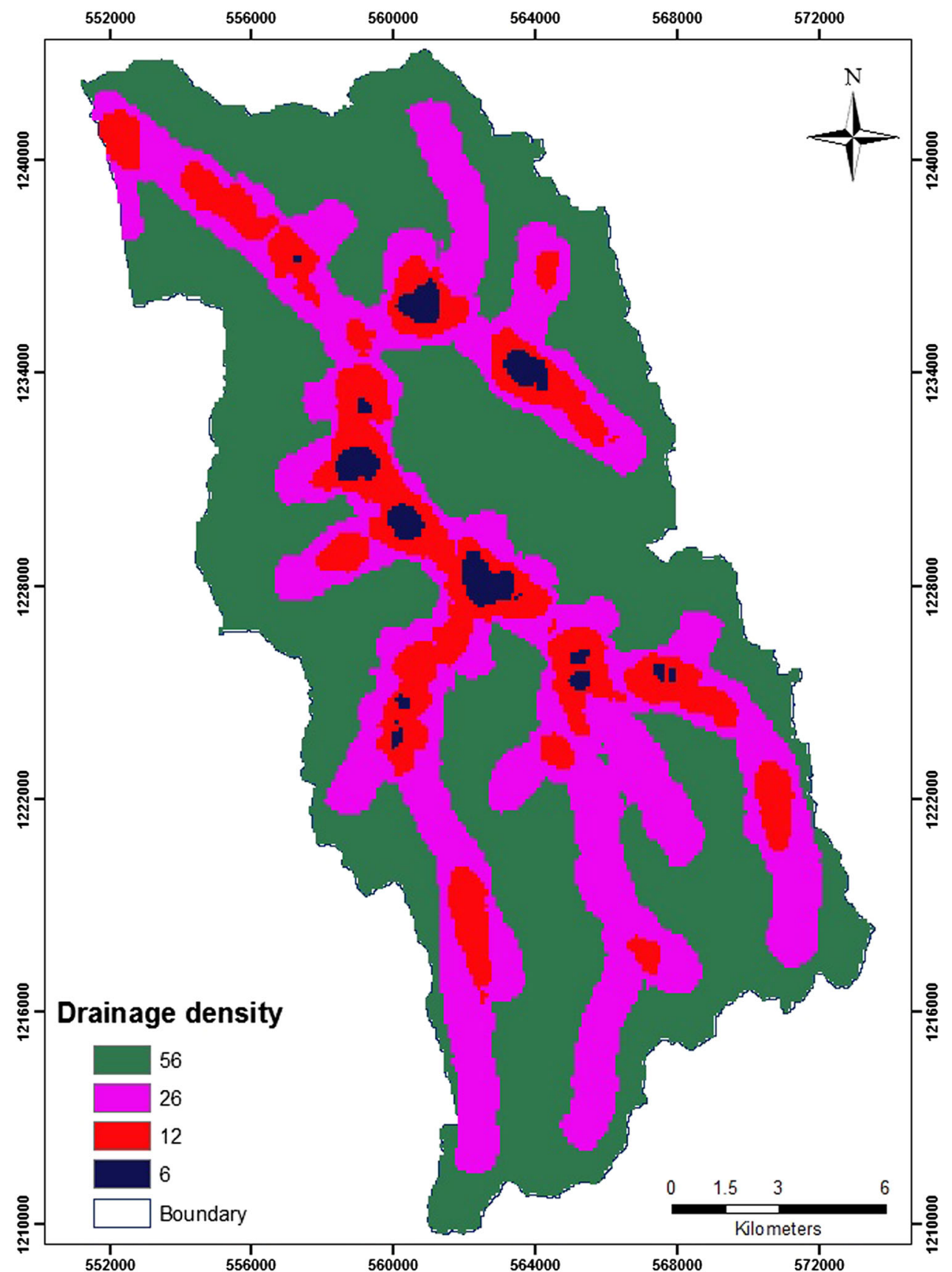

(Shaw 1988). This method is possibly the best of the three because it takes into account the local effects like prevailing wind and uneven topography.

The mean annual rainfall of the catchment was found $1180.3,1251.37$ and $1307.76 \mathrm{~mm}$, respectively, using Thiessen polygon, arithmetic mean and isohyetal interpolation methods. But, the annual mean obtained from isohyetal interpolation which is 1180.31 was considered for this purpose.

Rainfall is the major source of recharge. And it determines the amount of water that would be available to percolate into the groundwater system (Aggarwal et al. 2013). It is the fact that rainfall is the main source of the hydrologic cycle which plays an important role in the natural water cycle. It plays an important role in the hydrologic cycle, which controls groundwater potential. It can be seen from Fig. 6 that the annual rainfall of the catchment ranges from 1037 up to $1375 \mathrm{~mm}$. Hence, areas with high amount of rainfall are given more weighted value as compared to areas with low annual rainfall during the analysis of groundwater suitability analysis. 
Fig. 5 Land use land cover

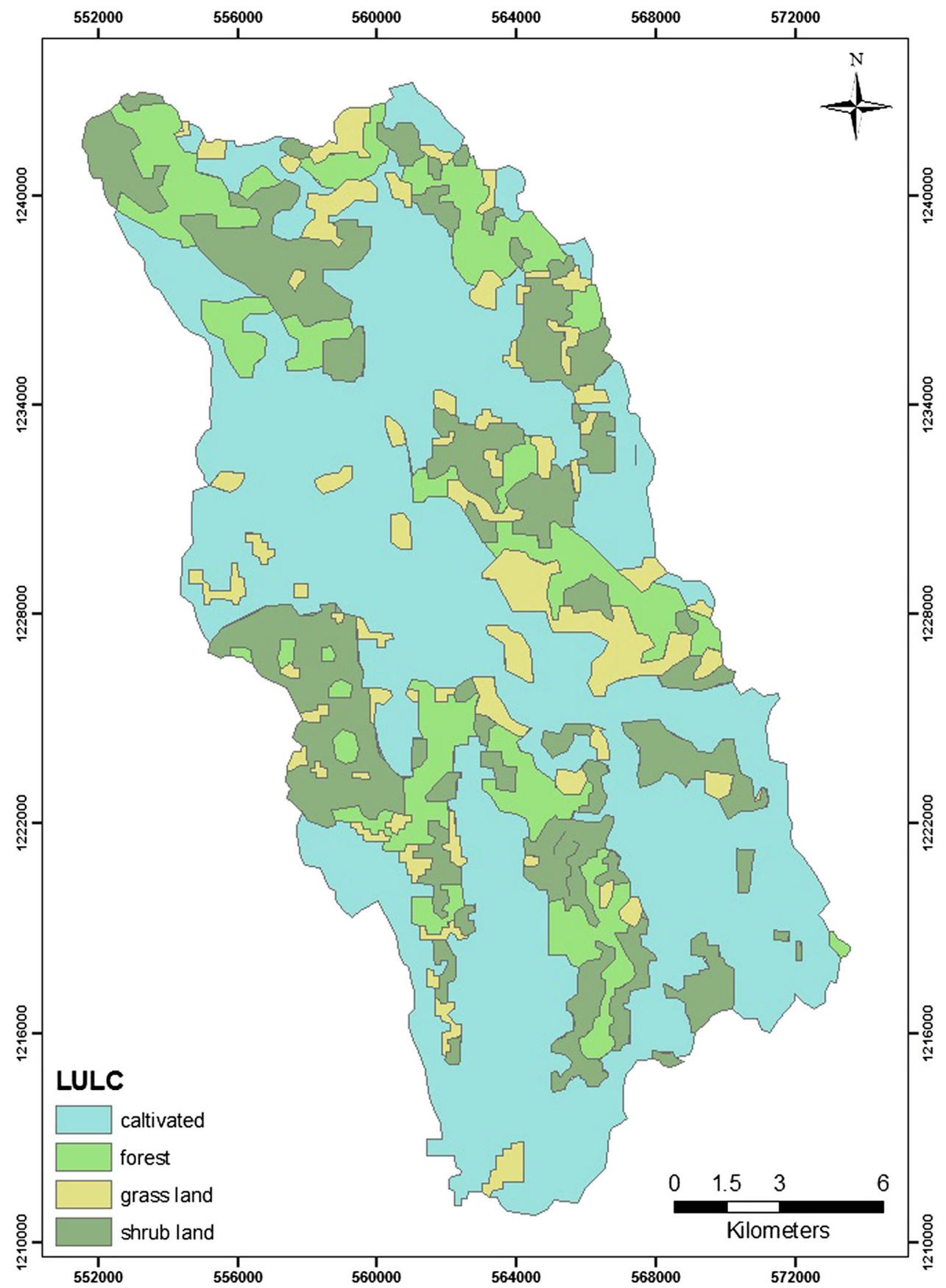

\section{Slope}

As shown in Fig. 7, the central part of the study area is highly covered by grazing and cultivating land that is flat having a slope degree value of $0^{\circ}-5^{\circ}$ and which is $69.62 \%$ of the catchment. The area with slope values of $5^{\circ}-12^{\circ}$ and $12^{\circ}-30^{\circ}$ is classified as gentle and moderate that covers 97 and $15 \mathrm{~km}^{2}$ which is 26.08 and $4.03 \%$ of the study area, respectively, which is covered by cultivation land.

The area around the south east and north parts of the catchment is steep having a slope value of $30^{\circ}-60^{\circ}$ and covers $1 \mathrm{~km}^{2}$ area. And it is equivalent to $0.27 \%$ of the catchment and covered by shrubs and plantation. Slope is one of the most important factors controlling groundwater incidence.

Flat areas are capable of holding the rainfall and facilitate recharge to groundwater as compared to steep slope area where water moves as runoff quickly (Sisay 2007). The finding further showed that slopes with flat $\left(<5^{\circ}\right)$ and gentle areas $\left(5^{\circ}-12^{\circ}\right)$ are more suitable for groundwater occurrence as compared to steep because gentle and flat slope areas permit less runoff and have very good potential 
Fig. 6 Rainfall of the study area

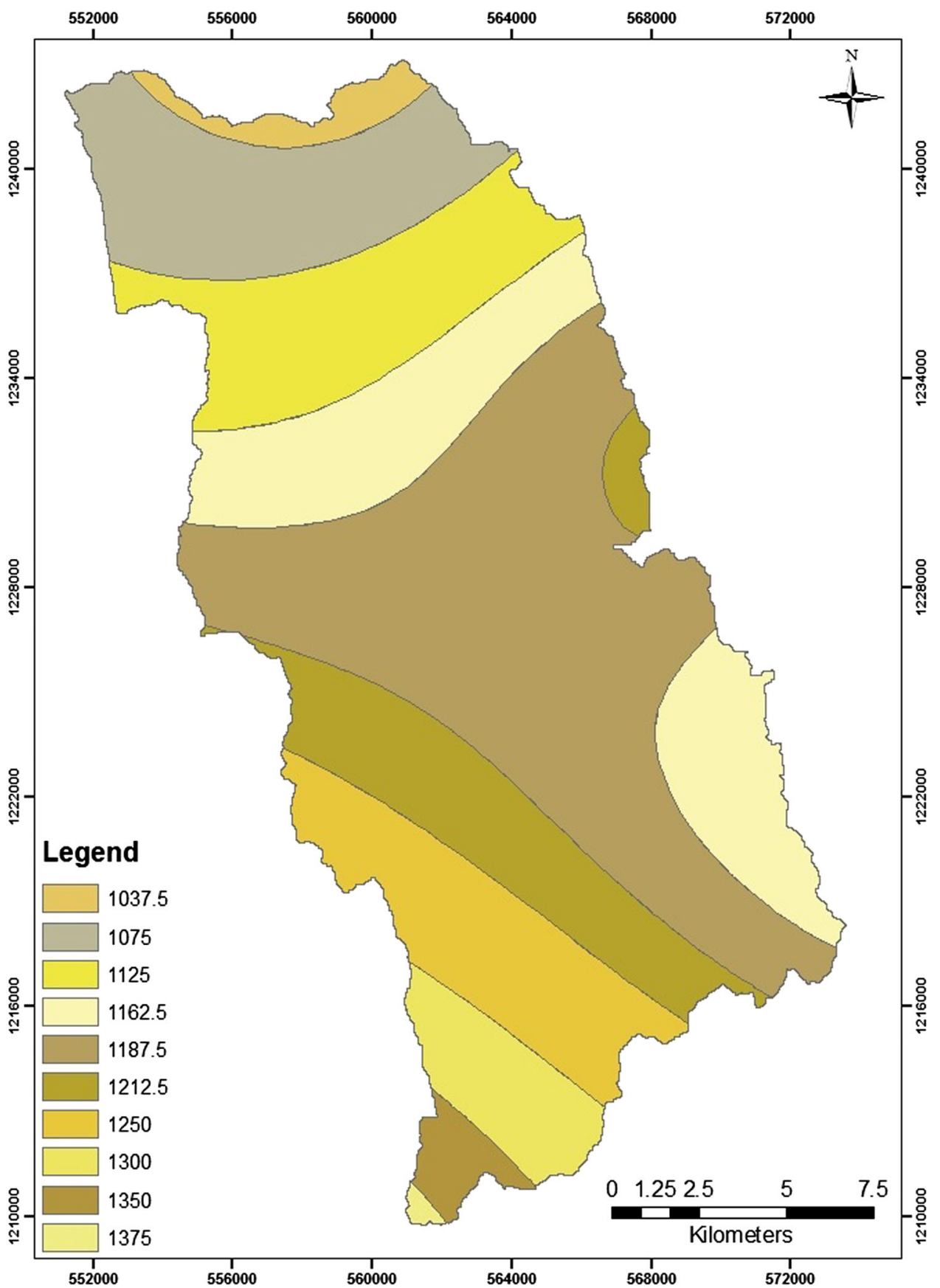

for groundwater presence. Topographic setting relates to the local and regional relief gives an idea about the general direction of groundwater flow and its influence on groundwater recharge and discharge (Tesfaye 2010).

\section{Soil}

The characteristics, types and distribution of soil for a certain area depend on geomorphology, geology, relief, time, and other factors. Soil properties influence the relationship between runoff and infiltration rates which in turn controls the degree of permeability that determines the groundwater potential (Tesfaye 2010). Soil texture is a medium that controls the groundwater vulnerability which is an important in determining the intrinsic vulnerability.

In line with FAO and according to the Ethiopian Ministry of Water Resource Soil Classification, the prevailing soil types in the study area were classified into three major groups, namely, cambisols, leptosols and regosols as shown in Fig. 8. The result showed that cambisols and leptosols soils are found the most dominant in terms of area coverage 
Fig. 7 Slope of the study area

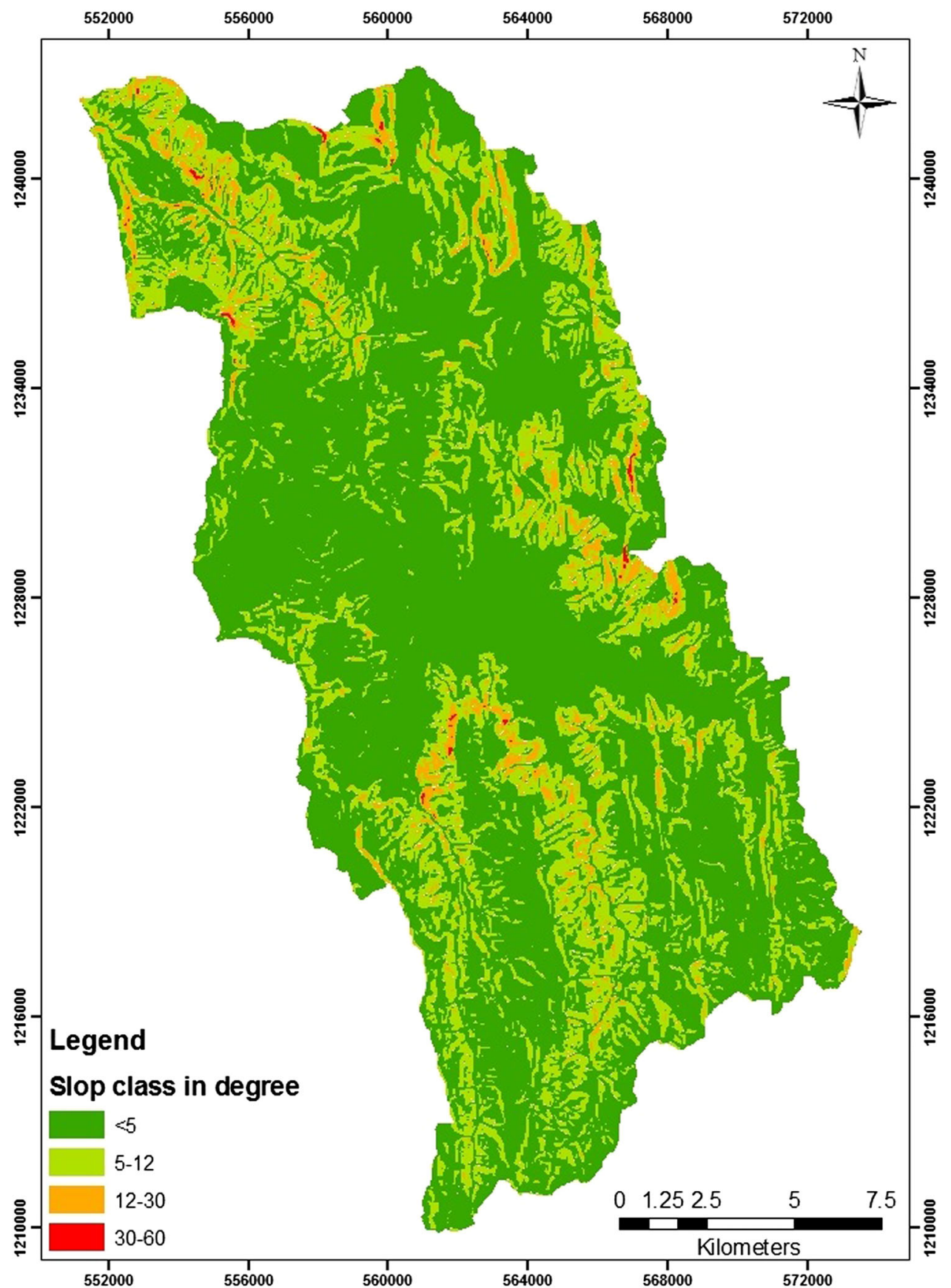

and more determinant in groundwater occurrence and movement as compared to leptosols and regosols.

\section{Lineament density}

Areas with higher lineament density facilitate infiltration and recharge of groundwater and, therefore, have good potential for groundwater development (Bhuvaneswaran et al. 2015). Moreover, areas with gentle slope permit less runoff and have very good potential for groundwater availability; see Fig. 10. The slope increases towards the south east and north parts of the study area that facilitates high runoff and poor groundwater recharge.

A high lineament length density indicates high secondary porosity, thus representing a zone with high groundwater potential (Al-Abadi and Al-Shamma'a 2014). As shown in Fig. 9, the groundwater suitability map, most of the potential areas are found with higher lineament density and gentle slopes. 
Fig. 8 Soil of the study area

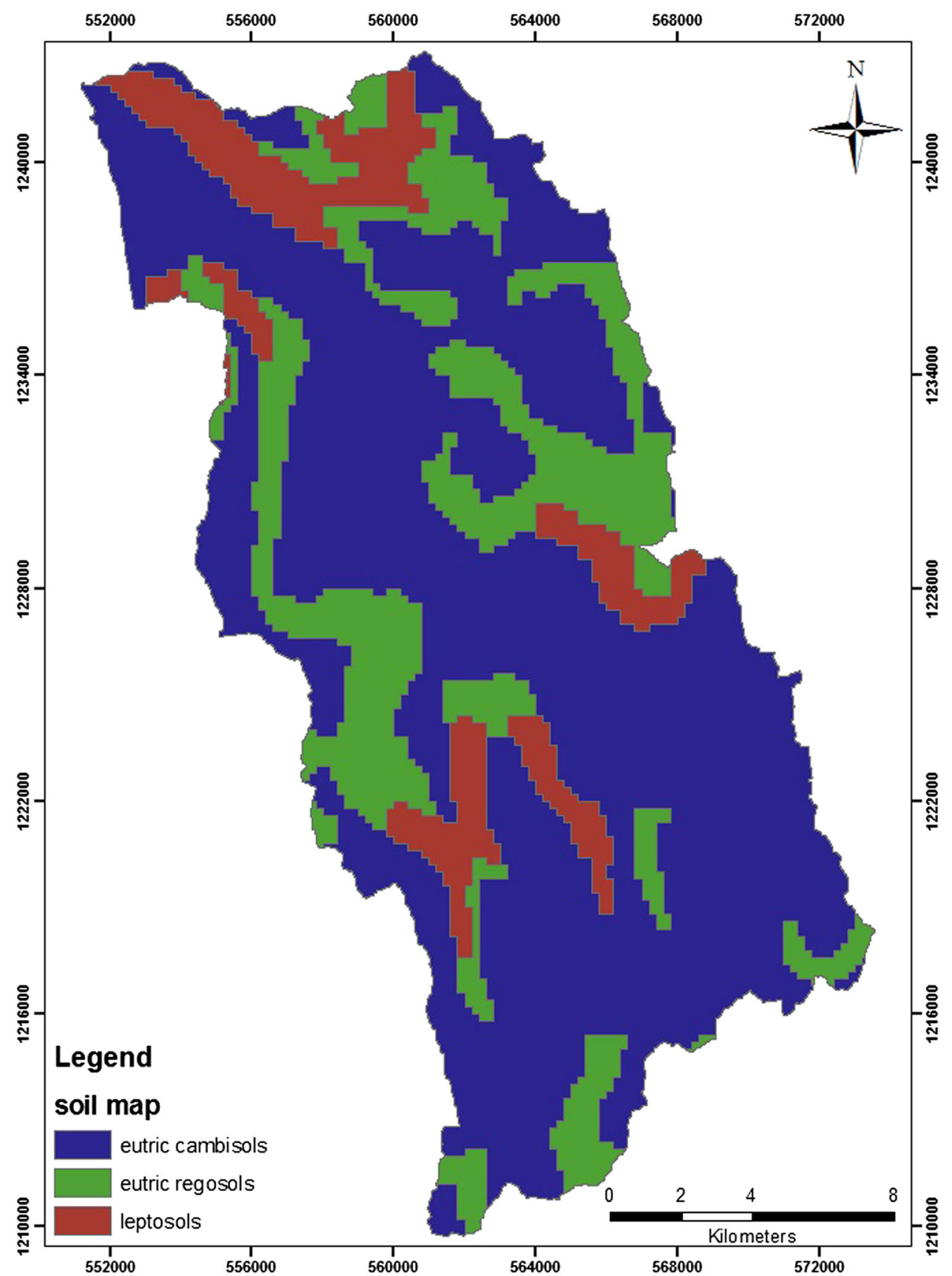

\section{Groundwater prospect map and validation}

To identify groundwater potential zones, factors such as geological structures, lithology, geomorphology, slope, land cover, drainage and others are very important to integrate through RS and GIS techniques and MCDA (Waikar and Nilawar 2014; Ayele et al. 2014; Sisay 2007; Dev 2015; Rose and Krishnan 2009). Groundwater arises within different hydrogeological environment, and topographic settings that control the groundwater distribution and development for different purposes (Tesfaye 2010).

For this research, the groundwater prospect map of the area was done by integrating eight thematic layers using weighted overlay method of ArcGIS software. GIS-based multi-criteria evaluation based on Saaty's Analytical Hierarchy Process (AHP) was used to compute the rates for the classes and weights and ranks for thematic layers (Arivalagan et al. 
Fig. 9 Lineament of the study area

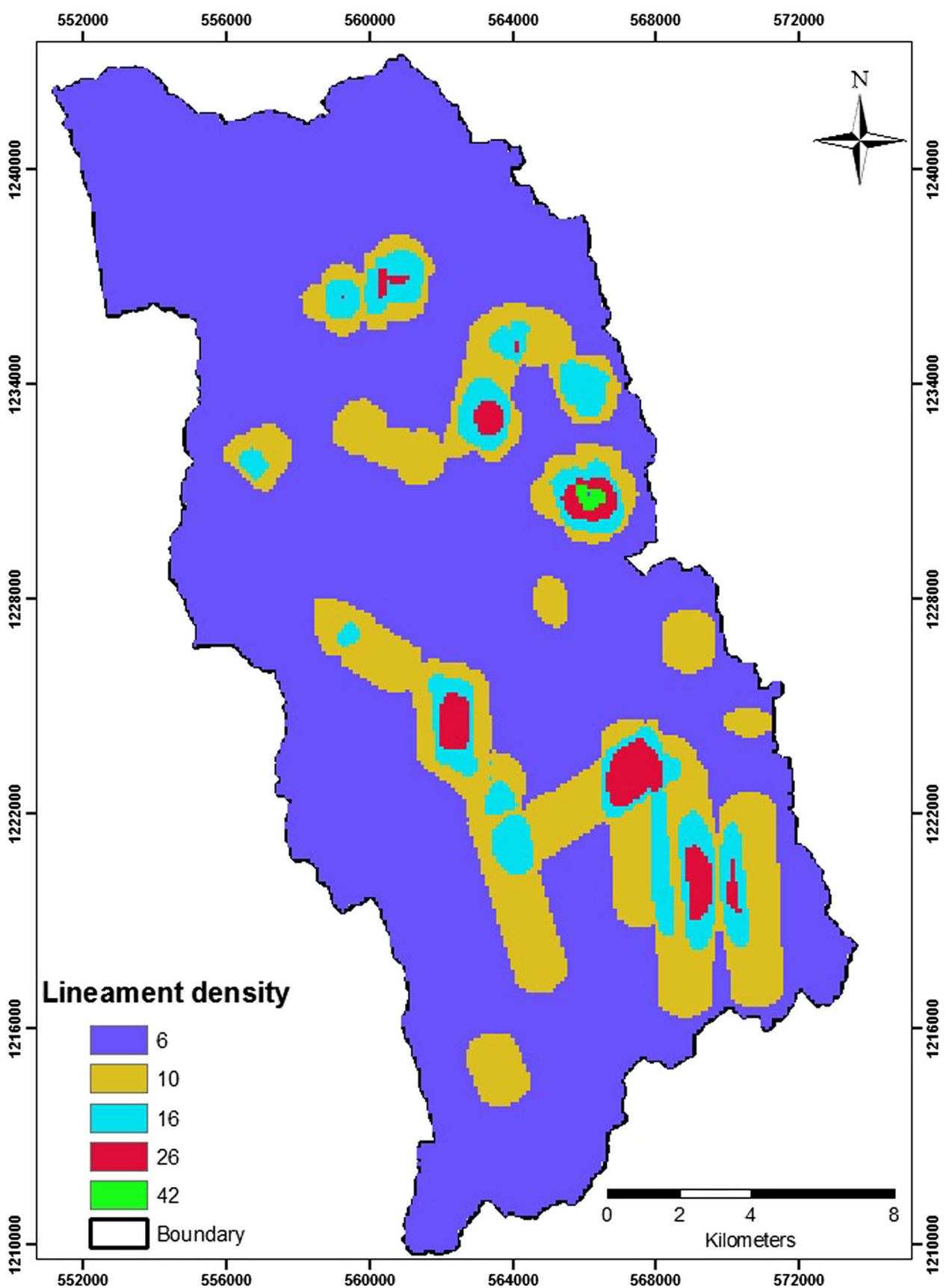

Table 1 Pairwise comparison matrix among thematic layers $(C R=0.0805)$

\begin{tabular}{lllllllllll}
\hline & LT & LD & GM & SL & SOL & DD & RF & $L$ & Weight & Weg $\times 100$ \\
\hline LT & 1 & 2 & 4 & 5 & 6 & 7 & 8 & 9 & 0.3453 & 34.53 \\
LD & $1 / 2$ & 1 & 2 & 4 & 5 & 6 & 7 & 8 & 0.2339 & 23.39 \\
GM & $1 / 4$ & $1 / 2$ & 1 & 2 & 4 & 5 & 6 & 7 & 0.1548 & 15.48 \\
SL & $1 / 5$ & $1 / 4$ & $1 / 2$ & 1 & 2 & 4 & 5 & 6 & 0.1033 & 10.33 \\
SOL & $1 / 6$ & $1 / 5$ & $1 / 4$ & $1 / 2$ & 1 & 2 & 4 & 5 & 0.0689 & 6.89 \\
DD & $1 / 7$ & $1 / 6$ & $1 / 5$ & $1 / 4$ & $1 / 2$ & 1 & 2 & 4 & 0.0449 & 4.49 \\
RF & $1 / 8$ & $1 / 7$ & $1 / 6$ & $1 / 5$ & $1 / 4$ & $1 / 2$ & 1 & 2 & 0.0286 & 2.86 \\
LULC & $1 / 9$ & $1 / 8$ & $1 / 7$ & $1 / 6$ & $1 / 5$ & $1 / 4$ & $1 / 2$ & 1 & 0.0203 & 2.03 \\
\hline
\end{tabular}




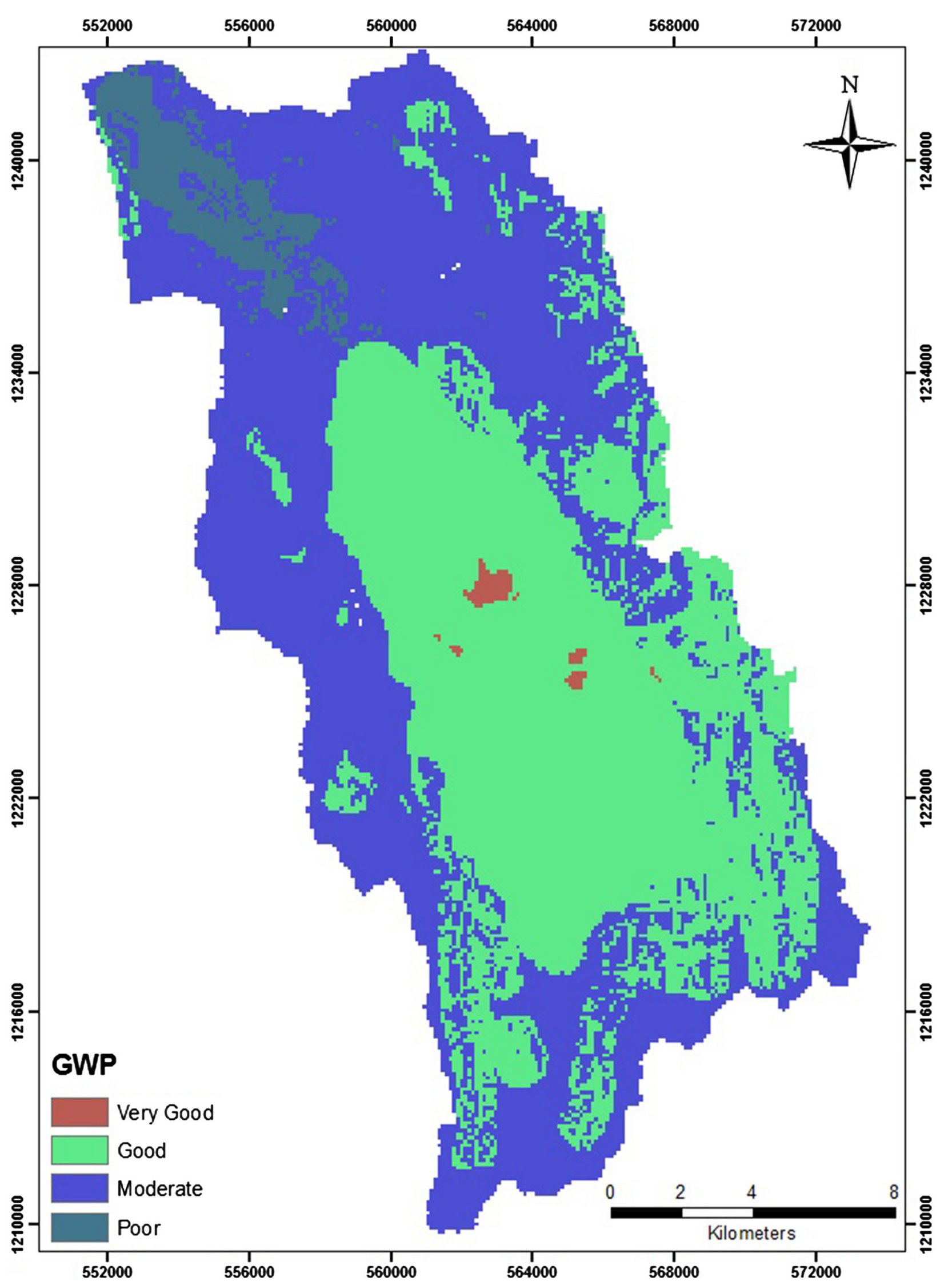

Fig. 10 Groundwater potential of the study area 
2015). This is because all those variables have no equal impact in determining groundwater occurrence and movement (Saaty 1980).

For all thematic layers, the CR value was found less than 0.1 and hence the judgments of the pairwise comparison within each thematic layer were acceptable (Saaty 1980). The most three factors affecting groundwater occurrence were found lithology with $(34.56 \%)$, lineament $(23.39 \%)$, and geomorphology (15.48\%), respectively, as given in Table 1.

On the other hand, the rest of the five least influencing factors were slope, soil, drainage density, rainfall, and land use/cover, respectively. At last, it involves spatial analysis to combine all thematic layers based on rates for the classes in a layer and weight of thematic layers from the pairwise comparison. The formula for computing the GWP map is given below:

$$
\begin{aligned}
\mathrm{GWP}= & 0.3456 \times \mathrm{LT}+0.2339 \times \mathrm{LD}+0.1548 \times \mathrm{GM} \\
& +0.1033 \times \mathrm{SL}+0.0689 \times \mathrm{SOL}+0.0449 \times \mathrm{DD} \\
& +0.0286 \times \mathrm{RF}+0.0203 \times \mathrm{LUL}
\end{aligned}
$$

where GWP is the groundwater potential, LT is the lithology, LD is the lineament density, GM is the geomorphology, SL is the slope, SOL is the soil, DD is the drainage density, RF is the rainfall, and LULC is the land use land cover.

Finally, the groundwater prospect map of the area was developed using weighted linear combination of the thematic layers and reclassified into four zones. So, finally groundwater map suitability was created with field values of ranging from very good to poor classes. The very good groundwater prospect zones are mostly in the alluvial plains/valleys, with smooth and irregular plain geomorphological classes.

And it coincides with flat to moderate slope classes. At last, groundwater zones produced are compared against borehole yield data to check the validity of the result. Olutoyin (2014), Singh (2014) and Soumen 2014 stated that validation of the groundwater potential zones should be done using existing data on dung wells and bore holes.

Thus, out of the collected and reviewed 60 water points, 57 have measured and estimated actual yield data. In general, the data indicated high yield ( $\geq 30 \mathrm{l} / \mathrm{s})$ in the very good potential areas while very low yield $(<51 / \mathrm{s})$ in the very poor potential areas. Intermediate values occurred in the zones between these extremes.

Water points with yield $5<12 \mathrm{l} / \mathrm{s}$ occur in the poor, with 12-17 1/s in the moderate, and 18.5-20 1/s in the good zones of groundwater potential. As shown in Fig. 10, most of the suitable groundwater areas are found in the central and eastern part of the study area. In contrast, the northern and western parts of the Gerado River Catchment have less prospective of groundwater incidence.

\section{Conclusion}

Adopting advanced geospatial techniques in groundwater evaluation and mapping is cost effective in terms of time and resource. This paper was an attempt to delineate and map out groundwater potential availability of Gerado River, in the Northern Ethiopia. The most important variables affecting groundwater controlling were considered, namely, geomorphology, lithology, slope, soil, LULC, lineament density, drainage density and rainfall.

But, since all those factors do not have equal importance in controlling groundwater, weighted value determination was done after all thematic maps were organized. Accordingly, lithology, lineament density, geomorphology and slope were found the most significant factors with a weighted of value of $34.56,23.39,15.48$ and $10.33 \%$, respectively. The suitable potential groundwater areas are found within lithology class of alluvia deposits and geomorphology class of alluvia plain, respectively. Moreover, areas with flat slope and low lineament density are also found the most potential areas of groundwater.

In contrast, the rest factors such as soil (6.89\%), drainage density $(4.49 \%)$, rainfall $(2.86 \%)$ and LULC $(2.03 \%)$ were found separately the least factors controlling groundwater occurence. If observe the spatial distribution of the groundwater suitability map, the least potential areas of areas are found in the western, northern and southern parts of the study area. And these are characterized by steep slope and high drainage density which facilitate run off creation and hence low potential groundwater potential.

In general, areas with very good and good class of groundwater map account for small areal coverage. Hence, it can be inferred that the study area has little groundwater potential suitability as compared to its total areal coverage. Furthermore, geospatial techniques with the help of MCDA are good tools to investigate the relationship among different geomorphological and environmental factors. Therefore, those tools are very effective and indispensible for planning and managing groundwater in a given watershed area.

Open Access This article is distributed under the terms of the Creative Commons Attribution 4.0 International License (http:// creativecommons.org/licenses/by/4.0/), which permits unrestricted use, distribution, and reproduction in any medium, provided you give appropriate credit to the original author(s) and the source, provide a link to the Creative Commons license, and indicate if changes were made. 


\section{References}

Aggarwal PK, Terzer S, Wassenaar LI, Araguás-Araguás LJ (2013) Global isoscapes for $\delta 18 \mathrm{O}$ and $\delta 2 \mathrm{H}$ in precipitation: improved prediction using regionalized climatic regression models. Hydrol Earth Syst Sci 17(11):4713-4728

Al-Abadi AM, Al-Shamma'a A (2014) Groundwater potential mapping of the major aquifer in Northeastern Missan Governorate, South of Iraq by using analytical hierarchy process and GIS. J Environ Earth Sci 10:125-149

Arivalagan J, Sleight VA, Thorne MA, Peck LS, Berland S, Marie A, Clark MS (2015) Characterisation of the mantle transcriptome and biomineralisation genes in the blunt-gaper clam, Mya truncata. Mar Genom 27:47-55. doi:10.1016/j.margen.2016.01.003

AWSD, Amhara Water Study, Design and Supervision Enterprise (2002) Geological, structural and geomorphological study and mapping in Eastern Amhara development corridor groundwater potential assessment project, Bahirdar, pp 20-62

Ayazi MH, Pirasteh S, Rizvi SM, Safari H, Ramli FM, Pradhan B, Rizvi SM (2010) Using ERS-1 synthetic aperture radar for flood delineation, Bhuj Taluk, Kuchch District Gujarat, India. Int Geoinform Res Dev J 1:13-22

Ayele AF, Addis K, Tesfamichael G, Gebrerufael Ha (2014) Spatial analysis of groundwater potential using remote sensing and GISbased multi-criteria evaluation in Raya valley, Northern Ethiopia. Hydrogeol J (2015) 23:195-206. doi 10.1007/s10040014-1198

Bayessa A et al (2002) Regional hydrogeological investigations of northern Ethiopia under Geological survey of Ethiopia (GSE), vol 16. Addis Ababa, Ethiopia, pp 22-36

Bhuvaneswaran C, Ganesh A, Nevedita S (2015) Spatial analysis of groundwater potential zones using remote sensing, GIS and MIF techniques in uppar Odai sub-watershed, Nandiyar, Cauvery basin, Tamilnadu. Int J Curr Res 7(09):20765-20774 [September, 2015gy| volume 1| issue 9| February 2015 ISSN (online): 2349-6010]

Bobba AG, Bukata RP, Jerome JH (1992) Digitally processed satellite data as a tool in detecting potential groundwater flow systems. J Hydrol 131(1-4):25-62

Chowdhury A, Jha MK, Machiwal D (2003) Application of remote sensing and GIS in groundwater studies: an overview. Proceedings of the international conference on water \& environment (WE-2003). Ground Water Pollution, 15-18 December 2003, MP, India, pp 39-50

Dereje G (2012) Groundwater potential assessment and water quality investigation. Gerado Dessie, M.Sc., thesis, Mekelle University, Ethiopia

De Villiers M (2000) Water: the fate of our most precious resource. Mariner Books, Houghton, Mifflin, Boston

Dev SG (2015) Groundwater potential mapping of Sihu river watershed area of Mahoba District, UP using Remote Sensing and GIS. IJAR 1(10):241-248

Foster S (1998) Groundwater assessing vulnerability and promoting protection of a threatened resource. In: Proceedings of the 8th Stockholm water symposium, Sweden, pp.79-90

Gogu RC, Carabin G, Hallet V, Peters V, Dassargues A (2001) GISbased hydrogeological databases and groundwater modeling. Hydrogeol J 9:555-569

Goodchild MF (1993) The state of GIS for environmental problemsolving. In: Goodchild MF, Parks BO, Steyaert LT (eds) Environmental modeling with GIS. Oxford University Press, New York, pp 8-15

Gossel W, Ebraheem AM, Wycisk P (2004) A very large scale GISbased groundwater flow model for the Nubian sandstone aquifer in Eastern Sahara (Egypt, northern Sudan and eastern Libya). Hydrogeol J 12(6):698-713

IWMI (2001) The strategic plan for IWMI 2000-2005. International Water Management Institute (IWMI), Colombo, pp 28-52

Loague K, Corwin DL (1998) Regional-scale assessment of non-point source groundwater contamination. Hydrol Process 12(6):957-966

Meijerink AMJ, Schultz GA, Engman ET (2000) Remote sensing in hydrology and water management. Springer, Berlin, pp 305-325

Murasingh S (2014) Analysis of groundwater potential zones using electrical resistivity, rs \& gis techniques in a typical mine area of odisha. Doctoral dissertation, National Institute of Technology Rourkela

Olutoyin A, Fashae MN, Tijani AO, Talabi OI (2014) Delineation of groundwater potential zones in the crystalline basement terrain of SW-Nigeria: an integrated GIS and remote sensing approach. Appl Water Sci 4:19-38. doi:10.1007/s13201-013-0127-9

Rose RS, Krishnan N (2009) Spatial analysis of groundwater potential using remote sensing and GIS in the Kanyakumari and Nambiyar basins, India. J Indian Soc Remote Sens 37(4):681-692

Saaty TL (1980) The analytic hierarchy process. McGraw-Hill, New York, p 278

Shaw EM (1988) Hydrology in practice, 2nd edn. Chapman and Hall, New York, p 539

Singh A (2014) Groundwater resources management through the applications of simulation modeling: a review. Sci Total Environ 499:414-423

Sisay L (2007) Application of remote sensing and GIS for groundwater potential zone mapping in Northern Ada'a plain (Modjo catchment) University/Publisher Addis Ababa University. http:// etd.aau.edu.et/dspace/handle/123456789/386

Solomon S, Ghebreab W (2008) Hard-rock hydrotectonics using geographic information systems in the central highlands of Eritrea: implications for groundwater exploration. J Hydrol 349(1): 147-155

Soumen D (2014) Delineation of ground water prospect zones using remote sensing, GIS techniques - a case study of Baghmundi development block of Puruliya district, West Bengal. Int J Geol Earth Environ Sci. ISSN: 2277-2081 (online). An open access, online international journal available at http://www.cibtech.org/ jgee.htm (2014) 4(2):62-72/Dey

Stafford KW, Rosales-Lagarde L, Boston PJ (2008) Castile evaporite karst potential map of the Gypsum Plain, Eddy County, New Mexico and Culberson County, Texas: a GIS methodological comparison. J Cave Karst Stud 70(1):35-46

Tesfaye T (2010) Ground water potential evaluation based on integrated GIS and RS techniques in Bilate river catchment, South rift valley of Ethiopia. Am Sci Res J Eng Technol Sci (ASRJETS). ISSN (Print) 2313-4410, ISSN (Online) $2313-4402^{\odot}$ Global Society of Scientific Research and Researchers. http://asrjetsjournal.org

Todd DK, Mays LW (2005) Groundwater hydrology, 3rd edn. Wiley, New york, p 636

Tsakiris G (2004) Water resources management trends, prospects and limitations. In: Proceedings of the EWRA symposium on water resources management: risks and challenges for the 21 st century, 2-4 September 2004, Izmir, pp 1-6

Waikar ML, Nilawar AP (2014) Identification of groundwater potential zone using remote sensing and GIS technique. Int $\mathrm{J}$ Innov Res Sci Eng Tech 3. (ISSN: 2319-8753)

Watkins B, Lu YC, Hart G, Daughtry C (1997) The current state of precision farming. Food Rev Inte 13(2):141-162 